\title{
Acute kidney injury secondary to thrombotic microangiopathy associated with idiopathic hypereosinophilic syndrome: a case report and review of the literature
}

\author{
Diana Curras-Martin*, Swapnil Patel, Huzaif Qaisar, Sushil K. Mehandru, Avais Masud, Mohammad A. Hossain, \\ Gurpreet S. Lamba, Harry Dounis, Michael Levitt and Arif Asif
}

\begin{abstract}
Background: Renal involvement in idiopathic hypereosinophilic syndrome is uncommon. The mechanism of kidney damage can be explained as occurring via two distinct pathways: (1) thromboembolic ischemic changes secondary to endocardial disruption mediated by eosinophilic cytotoxicity to the myocardium and (2) direct eosinophilic cytotoxic effect to the kidney.
\end{abstract}

Case presentation: We present a case of a 63-year-old Caucasian man who presented to our hospital with 2 weeks of progressively generalized weakness. He was diagnosed with idiopathic hypereosinophilic syndrome with multiorgan involvement and acute kidney injury with biopsy-proven thrombotic microangiopathy. Full remission was achieved after 8 weeks of corticosteroid therapy.

Conclusion: Further studies are needed to investigate if age and absence of frank thrombocytopenia can serve as a prognostic feature of idiopathic hypereosinophilic syndrome, as seen in this case.

Keywords: Idiopathic hypereosinophilic syndrome, Eosinophilic cytotoxicity, Thrombotic microangiopathy

\section{Introduction}

Idiopathic hypereosinophilic syndrome (HES) is characterized by an absolute eosinophil count greater than 1500 cells $/ \mathrm{mm}^{3}$ observed at least twice with a minimum interval of 4 weeks, multiorgan involvement, and presence of tissue damage without an identifiable underlying cause [1]. Renal involvement in HES varies from $7 \%$ to $36 \%$; however, kidney injury mediated by thrombotic microangiopathy (TMA) is rare [2]. To the best of our knowledge, only two cases of idiopathic HES [3] and one case of myeloproliferative-variant HES [4] have been reported. None of the reported cases achieved normal kidney function after treatment. The pathophysiology of

\footnotetext{
* Correspondence: diana.currasmartin@hackensackmeridian.org Department of Medicine, Internal Medicine Residency Program, Jersey Shore University Medical Center, Hackensack Meridian Health, Neptune, NJ 07753, USA
}

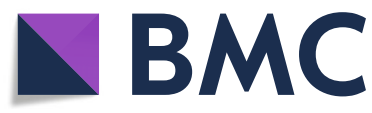

(c) The Author(s). 2019 Open Access This article is distributed under the terms of the Creative Commons Attribution 4.0 International License (http://creativecommons.org/licenses/by/4.0/), which permits unrestricted use, distribution, and reproduction in any medium, provided you give appropriate credit to the original author(s) and the source, provide a link to the Creative Commons license, and indicate if changes were made. The Creative Commons Public Domain Dedication waiver (http://creativecommons.org/publicdomain/zero/1.0/) applies to the data made available in this article, unless otherwise stated. renal impairment in HES can be explained by two mechanisms: (1) an ischemic kidney injury secondary to cardiac mural thrombus mediated by eosinophilic cytotoxicity to the heart (endocardium and myocardium) and (2) direct eosinophilic cytotoxic effect to the kidney [2-5]. We present a rare case of idiopathic HES with multiorgan failure and renal biopsy-proven TMA in which complete remission was achieved after 8 weeks of steroid therapy.

\section{Case presentation}

A 63-year-old Caucasian man presented to our hospital with 2 weeks of progressive generalized weakness, vague abdominal discomfort, and dyspnea on exertion requiring more frequent use of his inhaler. He did not report similar symptoms in the past, and he denied any associated chest pain, cough, changes in bowel habits, fevers, 
chills, weight loss, recent travel, tick bites, or sick contacts. His past medical history was relevant for chronic bronchitis diagnosed 10 years ago. He was a former onepack-per-day smoker for 20 years. His family history was noncontributory.

\section{Clinical findings}

The patient's vital signs at presentation showed a blood pressure of $128 / 84 \mathrm{mmHg}$, heart rate of 75 beats/minute, respiratory rate of 18 breaths/minute, oxygen saturation of $99 \%$ on room air, and body temperature of $97.7^{\circ} \mathrm{F}$. On physical examination, the patient was in no apparent distress and was awake, alert, and oriented to person, place, and time. His heart and lung examination revealed sinus tachycardia and diffuse expiratory wheezes throughout the lung fields. The patient's abdominal examination was pertinent for a nonperitonitic tenderness to palpation in the left upper quadrant. His neurological examination was remarkable for weakness in the right upper extremity. His laboratory data are summarized in Table 1.

\section{Timeline}

See Fig. 1 for the timeline of the patient's kidney function and absolute eosinophil count while receiving steroid treatment.

\section{Diagnostic assessment}

Findings of computed tomography (CT) of the patient's brain were unremarkable. Magnetic resonance imaging (MRI) of his brain revealed subacute infarcts involving the left frontal white matter and left cerebellum; in addition, an evolving subacute infarct was seen in the left corona radiata. CT of the chest demonstrated diffuse ground-glass opacity, and CT of the abdomen was remarkable for a wedge-shaped area of low attenuation in the spleen consistent with splenic infarct. His transthoracic echocardiogram revealed a mural apical thrombus in the left ventricular (LV) apex with reduced ejection fraction (31-35\%). Cardiac MRI performed 7 days after anticoagulation therapy was initiated showed a diffuse subendocardial scarring of the middle to apical LV segments and the right ventricular side of the septum. It also revealed evidence of edema of the middle anteroseptum and apical septum, consistent with endomyocardial fibrosis. However, no mural thrombus was visualized.

A presumptive diagnosis of HES was made on the basis of presenting symptoms, laboratory data, and imaging studies. Investigation for secondary causes, including immunological testing (Table 2), blood and urine cultures, ova and parasites, and infectious serology (Table 3), were unrevealing, and results of urine drug screening were negative. Bone marrow biopsy demonstrated a normocellular bone marrow population with eosinophilia comprising 60-70\%, without evidence of
Table 1 Laboratory data during hospitalization

\begin{tabular}{|c|c|c|}
\hline Biochemistry & Results & Reference values \\
\hline Sodium & 133 & $136-145 \mathrm{mmol} / \mathrm{L}$ \\
\hline Potassium & 4.0 & $3.5-5.2 \mathrm{mmol} / \mathrm{L}$ \\
\hline Chloride & 101 & $96-110 \mathrm{mmol} / \mathrm{L}$ \\
\hline Bicarbonate & 22 & $24-31 \mathrm{mmol} / \mathrm{L}$ \\
\hline Blood urea nitrogen & 17 & $5-25 \mathrm{mg} / \mathrm{dl}$ \\
\hline Creatinine & 1.3 & $0.61-1.24 \mathrm{mg} / \mathrm{dl}$ \\
\hline Glomerular filtration rate & 56 & $>60 \mathrm{ml} /$ minute \\
\hline Glucose & 87 & $70-99$ mg/dl \\
\hline Protein, total & 6.9 & $6.0-8.5 \mathrm{~g} / \mathrm{dl}$ \\
\hline Albumin & 2.8 & $3.5-4.7 \mathrm{~g} / \mathrm{dl}$ \\
\hline Aspartate aminotransferase & 40 & $10-42 \mathrm{IU} / \mathrm{L}$ \\
\hline Alanine transaminase & 51 & $10-60 \mathrm{IU} / \mathrm{L}$ \\
\hline Alkaline phosphatase & 128 & $38-126 \mathrm{IU} / \mathrm{L}$ \\
\hline Total bilirubin & 2.0 & $0.2-1.3 \mathrm{mg} / \mathrm{dl}$ \\
\hline Lactate dehydrogenase & 343 & 91-200 IU/L \\
\hline Haptoglobin & 41 & $40-268 \mathrm{mg} / \mathrm{dl}$ \\
\hline Troponin I & 0.13 & $>0.08 \mathrm{ng} / \mathrm{ml}$ \\
\hline Procalcitonin & 0.11 & $<0.05 \mathrm{ng} / \mathrm{ml}$; low-risk sepsis \\
\hline \multicolumn{3}{|l|}{ Complete blood count } \\
\hline Hemoglobin & 10.0 & $12.0-17.5 \mathrm{~g} / \mathrm{dl}$ \\
\hline Hematocrit & 30.2 & $36-53$ \\
\hline Red cell distribution width & 17.0 & $11.5-15.0 \%$ \\
\hline Mean corpuscular hemoglobin & 28.9 & $26.0-34.0 \mathrm{pg}$ \\
\hline Platelets & 190 & $140-450 \times 10^{3} / \mu l$ \\
\hline White cell count & 22.2 & $4.5-11.0 \times 10^{3} / \mu \mathrm{l}$ \\
\hline Neutrophil count & 4.8 & $1.50-7.50 \times 10^{3} / \mu \mathrm{l}$ \\
\hline Eosinophil count & 16.2 & $0.00-0.50 \times 10^{3} / \mu \mathrm{l}$ \\
\hline Erythrocyte sedimentation rate & 32 & 0-15 mm/hour \\
\hline International normalized ratio & 1.15 & $0.88-1.15$ \\
\hline
\end{tabular}

lymphoproliferative disorder or metastatic neoplasm. Cytogenetic analysis was unrevealing: negative for breakpoint cluster region-Abelson murine leukemia viral oncogene homolog 1 (BCR-ABL1) fusion, eosinophiliaassociated platelet-derived growth factor receptor alpha (PDGFRA), platelet-derived growth factor receptor beta (PDGFRB), fibroblast growth factor receptor 1 (FGFR1), Janus kinase $2(J A K 2)$ mutation, and JAK2 pericentriolar material 1 (PCM1) fusion.

Due to the stigma of hemolysis (normocytic acute anemia, elevated lactate dehydrogenase and bilirubin, positive schistocytes with relative thrombocytopenia), further investigation was pursued. The result of the Coombs test (direct and indirect) was negative. A disintegrin-like and metalloprotease with thrombospondin type 1 motif 13 (ADAMTS13) activity level was 


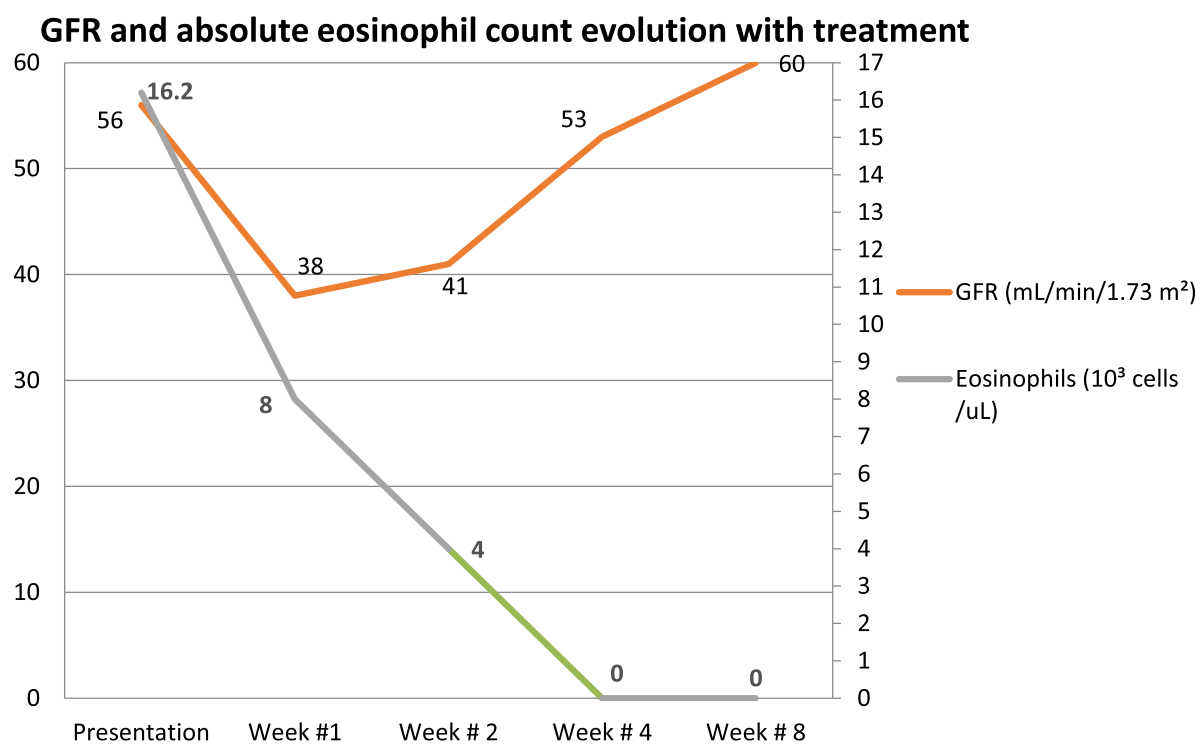

Fig. 1 Kidney function and absolute eosinophil count evolution on steroid treatment. GFR Glomerular Filtration Rate

greater than $50 \%$, and the expression of complement regulatory proteins CD59 and CD55 on erythrocytes was within normal limits as determined by flow cytometry.

Due to a further decline in the estimated glomerular filtration rate (GFR) early in the patient's hospital course, a kidney biopsy was pursued. Renal biopsy revealed a glomerular and vascular TMA, interstitial fibrosis, and inflammation with focal eosinophils (Fig. 1).

Table 2 Immunological test results

\begin{tabular}{|c|c|c|}
\hline Autoimmune serology & Results & Reference values \\
\hline Antinuclear antibody & 0.50 & $<0.90$, negative \\
\hline $\begin{array}{l}\text { Anti-double-stranded } \\
\text { DNA antibody }\end{array}$ & 1 & $<4 \mathrm{IU} / \mathrm{ml}$, negative \\
\hline Serine protease 3 antibody & 1 & 0-19 AU/ml \\
\hline Antineutrophil antibody & Positive & Negative \\
\hline Myeloperoxidase antibody & Not detected & $<1.0$, not detected \\
\hline Histone antibody lgG & 0.6 & $0.0-0.9$ units \\
\hline Cardiolipin IgA & 0.0 & $0-11$ units \\
\hline Cardiolipin IgM & 7.0 & $<20$ units, negative \\
\hline \multicolumn{3}{|l|}{ Complement } \\
\hline C4 & $15.6 \rightarrow 15.4$ & $16-40 \mathrm{mg} / \mathrm{dl}$ \\
\hline $\mathrm{C} 3$ & $91.7 \rightarrow 77$ & $85-170 \mathrm{mg} / \mathrm{dl}$ \\
\hline \multicolumn{3}{|l|}{ Immunoglobulins } \\
\hline $\lg G$ & 1240 & $600-1560 \mathrm{mg} / \mathrm{dl}$ \\
\hline $\lg M$ & 61 & $400-300 \mathrm{mg} / \mathrm{dl}$ \\
\hline $\lg A$ & 104 & $70-450 \mathrm{mg} / \mathrm{dl}$ \\
\hline $\lg E$ & 259 & $<214 \mathrm{Ku} / \mathrm{L}$ \\
\hline
\end{tabular}

DNA Deoxyribonucleic acid, Ig $\mathrm{G}$ Immunoglobulin $\mathrm{G}$, Ig $M$ Immunoglobulin $\mathrm{M}$, Ig A Immunoglobulin A, Ig $E$ Immunoglobulin $E$
IHC staining for eosinophil granule major basic protein 1 (MBP1) was not performed.

\section{Therapeutic intervention}

Our patient was started on prednisone $1 \mathrm{mg} / \mathrm{kg}$ daily and a heparin protocol at $18 \mathrm{U} / \mathrm{kg} /$ hour with an activated partial thromboplastin time goal of $60-100 \mathrm{sec}-$ onds. Simultaneously, warfarin was initiated. Once the

Table 3 Infectious disease test results

\begin{tabular}{lll}
\hline Infectious serology & Results & Reference values \\
\hline Human immunodeficiency virus & Negative & Negative \\
Hepatitis C virus & Negative & Negative \\
Hepatitis A virus IgM & Negative & Negative \\
Hepatitis D virus & Negative & Negative \\
Hepatitis B core IgM & Negative & Negative \\
Hepatitis B surface antibody & Negative & Negative \\
Hepatitis B surface antigen & Negative & Negative \\
QuantiFERON interpretation & Indeterminate & \\
QuantiFERON-TB & 0.00 & 0.00 IU/ml \\
Aspergillus antigen & Not detected & \\
Aspergillus fumigatus IgG & Negative & Negative \\
Micropolyspora faeni lgG & Negative & Negative \\
Pigeon serum & Negative & Negative \\
Thermoactinomyces candidus & Negative & Negative \\
Thymus vulgaris & Negative & Negative \\
Setaria viridis & Negative & Negative \\
Strongyloides antibody & Negative & Negative \\
\hline
\end{tabular}

IgG Immunoglobulin G, Ig M Immunoglobulin M 
patient's international normalized ratio was within therapeutic range (2.0-3.0), he was anticoagulated with heparin and warfarin for an additional 48 hours. His eosinophil count and estimated GFR were monitored on an outpatient basis, and his prednisone dose was gradually tapered. After the eighth week, the patient was maintained on $5 \mathrm{mg}$ of prednisone daily.

\section{Follow-up and outcomes}

By the time the renal biopsy report was available, the patient's kidney function had started to recover; hence, no further intervention was required. After initiation of treatment with steroids, the patient achieved resolution of pulmonary, cardiac, neurologic, and abdominal symptoms. Repeat echocardiography after 5 weeks showed improvement of LV ejection fraction to $50-55 \%$. Complete normalization of eosinophil count and renal function was observed after 4 and 8 weeks of therapy, respectively (Fig. 1). At his 10-week follow-up, the patient continued to do well under close surveillance for renal and cardiac complications. At 12-month follow-up, he continued to have a normal eosinophil count and renal function. However, cardiac MRI showed persistent endocardial fibrosis.

\section{Discussion}

HES is an uncommon disorder, marked by overproduction of eosinophils, eosinophilia greater than $1500 / \mathrm{mm}^{3}$, tissue infiltration, and organ damage. Idiopathic HES requires exclusion of primary and secondary causes of hypereosinophilia as well as lymphocyte-variant hypereosinophilia [1]. For the period from 2001 to 2005, the National Cancer Institute Surveillance, Epidemiology, and End Results Program reported an age-adjusted incidence of 0.036 per 100,000 person-years for myeloproliferative HES. The incidence of idiopathic HES remains obscure [6]. The most common presenting symptoms are weakness, fatigue, cough, and dyspnea, followed by fever, rash, rhinitis, and in rare cases angioedema [7]. The mortality of HES is close to $10 \%$, with the leading cause of death attributed to cardiac events followed by thromboembolic phenomena [8].

The pathogenesis of HES is mediated by "piecemeal degranulation" or eosinophil activation and secretion of the granule cationic proteins (such as eosinophil peroxidase, eosinophil cationic protein, eosinophil-derived neurotoxin, and MBP1) and eosinophil-expressed cytokines (such as RANTES [regulated on activation, normal $\mathrm{T}$ expressed and secreted] and interleukin [4, 9]). Eosinophil granule cationic proteins have the capability to activate inflammatory cells such as mast cells to induce inflammatory mediators and direct tissue-damaging cytotoxicity. These multiple proinflammatory activities lead to endothelial damage, thrombosis by activation of complement and coagulation cascade, and direct platelet stimulation and downregulation of thrombomodulin by MBP1 [5, 9].

Renal involvement in idiopathic HES is a rare entity, with only a handful of cases reported in the medical literature (Table 4) [10-21]. TMA is a life-threatening syndrome of systemic microvascular occlusions and is characterized by sudden or gradual onset of thrombocytopenia, microangiopathic hemolytic anemia, and renal or other end-organ damage [22]. It has been associated with diverse diseases and syndromes, such as systemic infections, cancer, pregnancy complications (for example, preeclampsia, eclampsia, HELLP [hemolysis, elevated liver enzymes, low platelet count] syndrome), autoimmune disorders (for example, systemic lupus erythematosus, systemic sclerosis, antiphospholipid syndrome), hematopoietic stem cell or organ transplant, severe hypertension, and cocaineinduced [22, 23]. Liapis et al. first reported two cases of

Table 4 Renal pathology in hypereosinophilia

\begin{tabular}{|c|c|c|c|}
\hline Patient age and sex & Diagnosis & Renal pathology & Reference \\
\hline 14-year-old female & Idiopathic HES & Thromboembolism & Spry [10] \\
\hline 50-year-old male & Idiopathic HES & Necrotizing IgA nephropathy & Shah et al. [11] \\
\hline 40-year-old male & Idiopathic HES & Interstitial nephritis & Bulucu et al. [12] \\
\hline 67-year-old woman & Idiopathic HES & Crescentic glomerulonephritis & Richardson et al. [13] \\
\hline 18-year-old male & Eosinophilic gastroenteritis & Immunotactoid glomerulonephritis & Choi et al. [14] \\
\hline 55-year-old male & Idiopathic HES & Interstitial nephritis, focal segmental glomerulosclerosis & Motellon et al. [15] \\
\hline 73-year-old male & Idiopathic HES & Ischemic changes, interstitial nephritis & Navarro et al. [16] \\
\hline 42-year-old male & HES & Renal Infarct & Smith et al. [17] \\
\hline 59-year-old male & HES & Interstitial nephritis & Garella et al. [18] \\
\hline 80-year-old female & Idiopathic HES & TTP & Ohguchi et al. [19] \\
\hline 40-year-old male & Idiopathic HES & ATN, Charcot-Leyden crystalluria & Hirszel et al. [20] \\
\hline 52-year-old male & Idiopathic HES & Membranous glomerulonephritis & Frigui et al. [21] \\
\hline
\end{tabular}

HES Hypereosinophilic syndrome, IgA Immunoglobulin A, ATN Acute tubular necrosis, TTP Thrombotic thrombocytopenic purpura 
TMA associated with idiopathic HES, along with a third case of myeloproliferative variant of HES in association with TMA [3] (Table 5). Of the cases described by Liapis et al., none had full renal recovery. In contrast, our patient did remarkably well with steroid and anticoagulation therapy. After discharge, his eosinophil count remained stable with resolution of renal injury with prednisone.

The mechanism of kidney damage in TMA with HES can occur via two different pathways: (1) direct eosinophilic cytotoxic effects to the renal vasculature and (2) ischemia secondary to thromboembolic events due to endocardial disruption. Subsequently, endothelial damage and complement cascade activation will result in TMA $[1,2,5]$. Similarly to our patient's case and cases reported previously, Spry [10] reported that one of every five patients with HES developed hypertension and some degree of proteinuria. However, the described patients presented late in the course of HES and most likely had ischemic changes to the kidney secondary to cardioembolism rather than intrinsic eosinophilic cytotoxicity [2].

A multicenter analysis demonstrated that steroids alone induced partial or complete response at 4 weeks of treatment in $85 \%$ of the patients [24]. It was also observed that patients with positive factor interacting with PAPOLA [poly(A) polymerase alpha] and CPSF1 (cleavage and polyadenylation specificity factor) (FIP1L1)-PDGFRA gene fusion had a higher response to imatinib than those without [24]. It has been hypothesized that the deletion of genetic material as

Table 5 Reported thrombotic microangiopathy cases: comparative table

\begin{tabular}{|c|c|c|c|c|}
\hline Demographics & Our patient & Historical 1 [3] & Historical 2 [3] & Historical 3 [4] \\
\hline Sex & Male & Male & Male & Male \\
\hline Age, years & 63 & 15 & 26 & 24 \\
\hline Race & Caucasian & African American & Caucasian & Caucasian \\
\hline \multicolumn{5}{|l|}{ CBC at admission } \\
\hline Hemoglobin $12.0-17.5 \mathrm{~g} / \mathrm{dl}$ & 10.0 & 9.8 & 13.3 & 10.7 \\
\hline Platelets $140-450 \times 10^{3} / \mu \mathrm{l}$ & $235^{\mathrm{a}}$ & 76 & 101 & 130 \\
\hline White cell count $4.5-11.0 \times 10^{3} / \mu \mathrm{l}$ & 22.2 & 23.7 & 14.7 & 23.5 \\
\hline \multicolumn{5}{|l|}{ Differential count, \% } \\
\hline Neutrophils $1.50-7.50 \times 10^{3} / \mu \mathrm{l}$ & 4.8 & 8.3 & 6.7 & Not available \\
\hline Lymphocytes $1.50-3.70 \times 10^{3} / \mu \mathrm{l}$ & 0.9 & 2.8 & 2.6 & Not available \\
\hline Monocytes $0.20-1.00 \times 10^{3} / \mu \mathrm{l}$ & 0.2 & 0.7 & 0.4 & Not available \\
\hline Eosinophils $0.00-0.50 \times 10^{3} / \mu \mathrm{l}$ & 16.2 & 11.1 & 4.9 & 18.3 \\
\hline Schistocytes & Positive & Not available & Positive & Positive \\
\hline \multicolumn{5}{|l|}{ Renal function test at admission } \\
\hline Creatinine $0.61-1.24 \mathrm{mg} / \mathrm{dl}$ & 1.3 & 10.9 & 2.2 & 1.81 \\
\hline GFR & 56 & Not available & 57 & 50 \\
\hline $\begin{array}{l}\text { Percentage eosinophils in bone } \\
\text { marrow }\end{array}$ & $60 \%$ & $80 \%$ & $44 \%$ & $37 \%$ \\
\hline Renal biopsy & $\begin{array}{l}\text { Glomerular capillary } \\
\text { thrombosis } \\
\text { Mesangiolysis } \\
\text { Endotheliosis } \\
\text { Eosinophilic infiltrate }\end{array}$ & $\begin{array}{l}\text { Arterial } \\
\text { thrombosis } \\
\text { Mesangiolysis } \\
\text { Eosinophilic } \\
\text { infiltrate }\end{array}$ & $\begin{array}{l}\text { Arteriolar thrombosis } \\
\text { Glomerular capillary } \\
\text { thrombosis } \\
\text { Eosinophilic infiltrate }\end{array}$ & $\begin{array}{l}\text { Arteriolar thrombosis } \\
\text { Glomerular capillary } \\
\text { thrombosis } \\
\text { Eosinophilic infiltrate }\end{array}$ \\
\hline \multicolumn{5}{|l|}{ Urinalysis } \\
\hline Proteinuria & Negative & Present & Present & Present \\
\hline Red blood cells/high-power field & 20 & 50 & Not available & 100 \\
\hline Eosinophils/high-power field & None & None & 7 & None \\
\hline Treatment & Prednisone & $\begin{array}{l}\text { Prednisone } \\
\text { Rituximab }\end{array}$ & $\begin{array}{l}\text { Prednisone } \\
\text { Imatinib }\end{array}$ & Imatinib \\
\hline Follow-up & At 2 months & At 6 months & At 12 months & At 12 months \\
\hline Creatinine $0.61-1.24 \mathrm{mg} / \mathrm{dl}$ & 1.18 & 5.2 & 1.8 & 1.7 \\
\hline
\end{tabular}

*Our patient's platelets at baseline: $377-348 \times 10^{3} / \mu \mathrm{l}$ 
occurs in HES may result in gain of fusion proteins [25].

We report the only patient treated solely with a steroid, and a complete resolution of acute kidney injury was achieved, in contrast to previously reported cases. We hypothesize that factors such as the patient's age group, proteinuria, and relative thrombocytopenia might be important to consider as prognostic factors.

\section{Conclusion}

TMA of the kidney in association with idiopathic HES is rare. To the best of our knowledge, this is the first case report of HES with multiorgan involvement that was successfully treated with a corticosteroid alone. Further studies are needed to investigate if age, absence of frank thrombocytopenia, and proteinuria can serve as prognostic features, as seen in our patient's case.

\section{Patient perspective}

Our patient has experienced a progressive recovery and is in good spirits.

\section{Authors' contributions}

$\mathrm{DCM}, \mathrm{SP}$, and $\mathrm{HQ}$ developed the idea for the report and wrote the manuscript with input from all the other authors. The manuscript was revised by all the authors. All authors read and approved the final manuscript.

\section{Funding}

This project was not supported by any grant or funding agency.

\section{Ethics approval and consent to participate}

Not applicable.

\section{Consent for publication}

Written informed consent was obtained from the patient for publication of this case report and any accompanying images. A copy of the written consent is available for review by the Editor-in-Chief of this journal.

\section{Competing interests}

The authors declare that they have no competing interests.

Received: 5 December 2018 Accepted: 4 July 2019

Published online: 05 September 2019

\section{References}

1. Gotlib J. World Health Organization-defined eosinophilic disorders: 2017 update on diagnosis, risk stratification, and management. Am J Hematol. 2017:92(11):1243-59.

2. Shehwaro N, Langlois AL, Gueutin V, Izzedine H. Renal involvement in idiopathic hypereosinophic syndrome. Clin Kidney J. 2013;6(3):272-6.

3. Liapis H, Ho AK, Graeme DB, Gleich MG. Thrombotic microangiopathy associated with the hypereosinophilic syndrome. Kidney Int. 2005;67(5): 1806-11.

4. Langlois AL, Shehwaro N, Rondet C, Benbrik Y, Maloum K, Gueutin V, Rouvier P, Izzedine H. Renal thrombotic microangiopathy and FIP1L1/ PDGFRa-associated myeloproliferative variant of hypereosinophilic syndrome. Clin Kidney J. 2013;6(4):418-20.

5. Ackerman SJ, Bochner BS. Mechanisms of eosinophilia in the pathogenesis of hypereosinophilic disorders. Immunol Allergy Clin N Am. 2007;27(3):357-75.

6. Crane MM, Chang CM, Kobayashi MG. Incidence of myeloproliferative hypereosinophilic syndrome in the Unites States and an estimate of all hypereosinophilic syndrome incidence. J Allergy Clin Immunol. 2010;126:179-81.

7. Weller PF, Bubley GJ. The idiopathic hypereosinophilic syndrome. J Am Soc Hematol Blood. 1994;83:2759-79.
8. Podjasek JC, Butterfield JH. Mortality in hypereosinophilic syndrome: 19 years of experience at Mayo Clinic with a review of the literature. Leuk Res. 2013;37(4):392-5.

9. Thomas LL, Page SM. Inflammatory cell activation by eosinophil granule proteins. Chem Immunol. 2000;76:99-117.

10. Spry CJ. Hypereosinophilic syndrome: clinical features, laboratory findings and treatment. Allergy. 1982;37:539-51.

11. Shah TH, Koul AN, Shah S, Khan UH, Koul PA, Sofi FA, Mufti S, Jan RA. Idiopathic hypereosinophilic syndrome presenting as IgA Nephropathy with nephrotic range proteinuria. Open J Nephrol. 2013;3(2):101-3.

12. Bulucu F, Can C, Inal V, Baykal Y, Erikçi S. Renal involvement in a patient with idiopathic hypereosinophilic syndrome. Clin Nephrol. 2002;57(2):171-3.

13. Richardson P, Dickinson G, Nash S, Hoffman L, Steingart R, Germain M. Crescentic glomerulonephritis and eosinophilic interstitial infiltrates in a patient with hypereosinophilic syndrome. Postgrad Med J. 1995;71(833):175-8.

14. Choi YJ, Lee JD, Yang KI, et al. Immunotactoid glomerulopathy associated with idiopathic hypereosinophilic syndrome. Am J Nephrol. 1998;18:337-43.

15. Motellon JL, Bernis, Garcia-Sanchez A, Gruss E, Tarver JA. Renal involvement in the hypereosinophilic syndrome: case report. Nephrol Dial Transplant. 1995;10:401-3.

16. Navarro I, Torras J, Goma M, Cruzado JM, Grinyó JM. Renal involvement as the first manifestation of hypereosinophilic syndrome: a case report. NDT Plus. 2009:2(5):379-81.

17. Smith A, Fernando SL. Renal infarction in hypereosinophilic syndrome. Intern Med J. 2012;42:1162-3.

18. Garella G, Marra L. Hypereosinophilic syndrome and renal insufficiency [in Italian]. Minerva Urol Nefrol. 1990;42:135-6.

19. Ohguchi H, Sugawara T, Harigae H. Thrombotic thrombocytopenic purpura complicated with hypereosinophilic syndrome. Inter Med. 2009:48:1687-90.

20. Hirszel P, Cashell AW, Whelan TV, et al. Urinary Charcot-Leyden crystals in the hypereosinophilic syndrome with acute renal failure. Am J Kidney Dis. 1988;12:319-22.

21. Frigui $M$, Hmida MB, Jallouli M, et al. Membranous glomerulopathy associated with idiopathic hypereosinophilic syndrome. Saudi J Kidney Dis Transpl. 2010;21:320-2.

22. Asif A, Ali Nayer A, Haas CS. Atypical hemolytic uremic syndrome in the setting of complement-amplifying conditions: case reports and a review of the evidence for treatment with eculizumab. J Nephrol. 2017:30(3):347-62

23. Dejman A, Alavi SN, Thomas DB, Stefanovic A, Asif A, Nayer A. The potential role of complements in cocaine-induced thrombotic microangiopathy. Clin Kidney J. 2018;11(1):26-8.

24. Ogbogu PU, Bochner BS, Butterfield JH, Gleich GJ, Huss-Marp J, Kahn JE, Leiferman KM, Nutman TB, Pfab F, Ring J, Rothenberg ME, Roufosse F, Sajous MH, Sheikh J, Simon D, Simon HU, Stein ML, Wardlaw A, Weller PF, Klion AD. Hypereosinophilic syndrome: a multicenter, retrospective analysis of clinical characteristics and response to therapy. J Allergy Clin Immunol. 2009;124(6):1319-25.

25. Cools J, DeAngelo DJ, Gotlib J, Stover EH, Legare RD, Cortes J, Kutok J, Clark J, Galinsky I, Griffin JD, Cross NC, Tefferi A, Malone J, Alam R, Schrier SL, Schmid J, Rose M, Vandenberghe P, Verhoef G, Boogaerts M, Wlodarska I, Kantarjian H, Marynen P, Coutre SE, Stone R, Gilliland DG. A tyrosine kinase created by fusion of the PDGFRA and FIPIL1 genes as a therapeutic target of imatinib in idiopathic hypereosinophilic syndrome. N Engl J Med. 2003; 348(13):1201-14

\section{Publisher's Note}

Springer Nature remains neutral with regard to jurisdictional claims in published maps and institutional affiliations.

Ready to submit your research? Choose BMC and benefit from:

- fast, convenient online submission

- thorough peer review by experienced researchers in your field

- rapid publication on acceptance

- support for research data, including large and complex data types

- gold Open Access which fosters wider collaboration and increased citations

- maximum visibility for your research: over $100 \mathrm{M}$ website views per year

At $\mathrm{BMC}$, research is always in progress.

Learn more biomedcentral.com/submission 